\title{
Phenotypes of Galactosaemia in Infants Screened at Birth
}

\author{
SALLY KELLY, LUCILLE DESJARDINS, PAUL ARMERDING, and JEAN BURNS
}

\author{
From the New York State Department of Health, Albany, New York
}

\begin{abstract}
Summary. Five genetic forms of galactosaemia were found in 15 infants identified in a newborn screening programme through a combination of laboratory criteria, involving serial assays of transferase and interpretation of isozyme patterns. The biochemical phenotypes of some infants were ascertained only weeks after birth, when transferase activities had increased from initial levels.
\end{abstract}

Any one of several phenotypes of galactosaemia are likely to be found in the infant with an abnormal screening test result at birth. Ascertained by analysing several kinds of biochemical data, phenotyping is an important corollary to the screening programme, as the genetic form of galactosaemia may determine the prognosis, course of treatment, and need for genetic counselling.

We assigned the biochemical phenotypes of galactosaemia in infants with apparent deficiencies of galactose-1-phosphate uridyl transferase, detected in a newborn screening programme (Kelly et al, 1970), by applying the criteria listed in Table I and, in some instances, by including data from serial assays of the transferase and family studies.

TABLE I

BIOCHEMICAL CHARACTERISTICS OF GALACTOSE-1-PHOSPHATE URIDYL TRANSFERASE USED AS CRITERIA FOR ASSIGNING PHENOTYPES OF GALACTOSAEMIA

\begin{tabular}{|c|c|c|}
\hline \multirow{2}{*}{ Phenotype } & \multicolumn{2}{|c|}{ Transferase } \\
\hline & Activity & Mobility \\
\hline $\begin{array}{l}\text { Normal } \\
\text { Galactosaemic- } \\
\text { homozygous } \\
\text { Galactosaemic- } \\
\text { heterozygous } \\
\text { Duarte variant- } \\
\text { homozygous } \\
\text { Duarte variant- } \\
\text { heterozygous } \\
\text { Galactosaemic/Duarte- } \\
\text { heterozygous }\end{array}$ & $\begin{array}{l}\text { Normal } \\
\text { Absent } \\
\text { Less than normal } \\
\text { Less than normal } \\
\text { Less than normal } \\
\text { Practically none }\end{array}$ & $\begin{array}{l}\text { Normal } \\
\text { Absent } \\
\text { Normal } \\
\text { Duarte (fast) } \\
\begin{array}{l}\text { Normal and Duarte (2 } \\
\text { bands) }\end{array} \\
\text { Duarte (fast) }\end{array}$ \\
\hline
\end{tabular}

\section{Materials and Methods}

The genetic forms of galactosaemia were classified in

Received 18 September 1972.
15 infants whose blood samples at birth, among 105,000 newborns screened, failed to develop maximum fluorescence in Beutler's spot test for galactosaemia (Beutler and Baluda, 1966a). The infants' physicians, Drs Selma Snyderman, Benjamin Effron, Charles W. Neuhardt, Richard Cooley, Frank Frascati, and William Bissell, described them as healthy, and the few given galactosefree diets on the basis of grossly abnormal initial test results received them prophylactically.

We measured the erythrocyte transferase on one or more occasions, as the infants developed, by fluorescent spot (Beutler and Baluda, 1966a), uridine diphosphoglucose consumption (UDPG) (Beutler and Baluda, 1966b), or fluorometric methods (Beutler and Mitchell, 1968) and compared the data with the parents' transferase, when available. The isozymes were separated by electrophoresis through horizontal starch gels with buffers of Tris (hydroxymethyl) amino methane hydrochloride and ethylenediamine tetra-acetic acid of $p \mathrm{H} \mathrm{8.8}$ for 17 hours (Mathai and Beutler, 1966; Ng et al, 1969) and the patterns examined under long-wave ultraviolet rays. Isozymes in normal blood and in blood from a patient of Dr Ernest Beutler's with the Duarte variant transferase served as controls.

Our range of normal transferase activities (Table II) obtained in UDPG consumption and fluorometric assays of blood from nine healthy adults and nine non-galactosaemic infants, 6 months old or younger, was similar to that reported for normal persons by the UDPG consumption method (Beutler and Baluda, 1966b) and slightly lower than that by the fluorometric method (Beutler and Mitchell, 1968).

\section{Results}

We recognized five phenotypes of galactosaemia among the 15 infants whose transferase characteristics are summarized in Table II. These were homozygous normal, homozygous classical galacto- 
TABLE II TRANSFERASE ACTIVITIES AND ISOZYME PATTERNS IN 15 INFANTS
WHOSE SCREENING TEST RESULTS FOR GALACTOSAEMIA AT BIRTH
WERE ABNORMAL

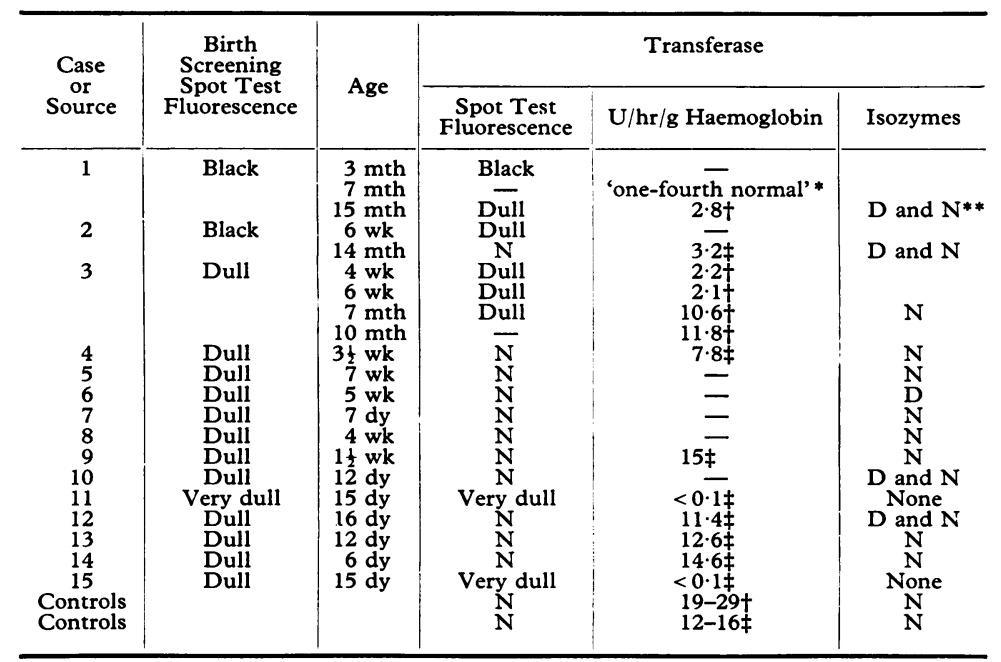

* Personal communication, Dr Selma Snyderman

+ UDPG method.

$¥$ Fluorometric method.

** $\mathrm{D}=$ Duarte, $\mathrm{N}=$ normal.

saemia, heterozygous classical galactosaemia, homozygous Duarte variant, and heterozygous Duarte variant. The phenotype of the double galactosaemia/Duarte variant heterozygote was not identified (Beutler et al, 1966).

Three infants (cases 9, 13, and 14) were considered normal homozygotes. The transferase in later samples was in the normal range and displayed the electrophoretic pattern of the normal isozyme.

Two infants (cases 11 and 15) were biochemical phenotypes of homozygous classical galactosaemia and were given galactose-free diets. The screening test result of case 11 was grossly abnormal, and neither cases 11 or 15 had demonstrable transferase at two weeks of age.

Cases 3 and 4 were assigned phenotypes of heterozygous classical galactosaemia. Transferase activities were less than normal, and the electrophoretic pattern was a single band with the mobility of the enzyme from carriers and normal persons. The parents of case 3 were apparently heterozygotes, as both were partially enzyme deficient (Table III).

Transferase of case 6 had electrophoretic properties of the Duarte variant homozygote (Fig. 1).

Transferase of cases $1,2,10$, and 12 were biochemically similar to that found in Duarte variant heterozygotes in that two isozymes were separated
TABLE III

TRANSFERASE ACTIVITY AND ISOZYME PATTERNS IN THREE INFANTS WITH ABNORMAL SCREENING TEST RESULTS FOR GALACTOSAEMIA AT BIRTH AND IN THEIR FAMILIES

\begin{tabular}{|c|c|c|c|}
\hline & \multirow{2}{*}{ Age } & \multicolumn{2}{|c|}{ Transferase } \\
\hline & & $\mathrm{U} / \mathrm{hr} / \mathrm{g}$ Haemoglobin & Isozymes \\
\hline $\begin{array}{l}\text { Case } 1 \\
\text { Father } \\
\text { Mother }\end{array}$ & $15 \mathrm{mth}$ & $\begin{array}{rr}2.8^{*} & 1.7 \dagger \\
12.3^{*} & 3.7 \dagger \\
16.9 * & 13.4 \dagger\end{array}$ & $\begin{array}{l}D \text { and } N \\
D \text { and } N\end{array}$ \\
\hline $\begin{array}{l}\text { Case } 2 \\
\text { Father } \\
\text { Mother }\end{array}$ & $14 \mathrm{mth}$ & $\begin{array}{l}3 \cdot 2 t \\
6 \cdot 5 t \\
5 \cdot 2 t\end{array}$ & $\begin{array}{l}D \text { and } N \\
D \text { and } N \\
D \text { and } N\end{array}$ \\
\hline $\begin{array}{l}\text { Case } 3 \\
\text { Father } \\
\text { Mother }\end{array}$ & $10 \mathrm{mth}$ & $\begin{array}{r}11 \cdot 8^{*} \\
11 \cdot 4^{*} \\
6 \cdot 2^{*}\end{array}$ & $\frac{N}{-}$ \\
\hline $\begin{array}{l}\text { Controls* } \\
\text { Controls } †\end{array}$ & - & $\begin{array}{l}19-29 \\
12-16\end{array}$ & $\mathbf{N}$ \\
\hline
\end{tabular}

* UDPG method.

t Fluorometric method.

and moved at rates comparable to the normal and Duarte variant enzymes. The bands were of various intensities in the four samples and may have reflected the different total activities expressed in the quantitative assays, ranging from 2.8 to 11.4 units/g haemoglobin. Activities and isozyme patterns in the parents of cases 1 and 2 were compatible with the interpretation (Table III).

The phenotypes of cases 5,7 , and 8 were not 


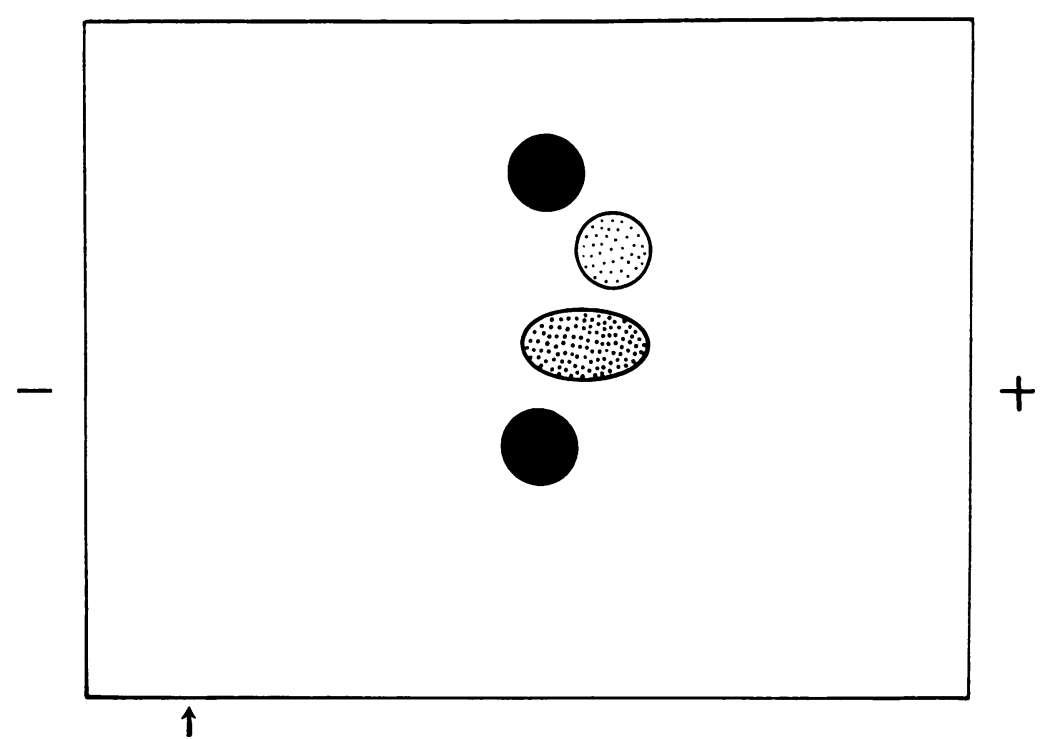

Fig. 1. Tracing of photographed electrophoretic patterns of normal and Duarte variant red cell galactose-1-phosphate uridyl transferase on starch gel. Top to bottom: normal control; Duarte homozygote control; case 1 (Duarte heterozygote); normal control.

The electrophoretic patterns of the erythrocyte transferases in the carrier of classical galactosaemia and of the 'double' Duarte/galactosaemia carrier are similar to those of the normal and Duarte homozygotes, respectively. The phenotypes, in these instances, are distinguished by transferase activity and family studies.

characterized because samples were not available for the quantitative assay of transferase activity. The data we have, normal fluorescent spot tests results several weeks after the initial screening test result and normal isozyme patterns, suggest the normal phenotype, but do not exclude that of the galactosaemia heterozygote.

\section{Discussion}

Five biochemical phenotypes were recognized in 15 infants, identified at birth as apparently transferase deficient in Beutler's fluorescent spot test for galactosaemia. A combination of criteria were applied in the ascertainment, including serial estimates of transferase activity, delineation of isozyme patterns, and characterization of the parents' transferases.

The rising transferase level in the two infant carriers of the Duarte variant and the carrier of classical galactosaemia suggests that biochemical phenotypes of heterozygotes may change with development and that partial enzyme deficiencies uncovered in the screening test at birth may lessen with age. Conversely, definition of the biochemical phenotype reassures the physician who must decide the treatment for his transferase-deficient, healthy patient.

The variable intensities of the isozyme fractions of the Duarte variant carriers and the variable range of total transferase activities in both kinds of carriers may be biochemical expressions of the genetic heterogeneity of galactosaemia, a characteristic of other well-studied inborn errors of metabolism.

We made no attempt to estimate gene frequencies on the basis of heterozygote frequency in the population screened, as our ascertainment of numbers was incomplete, inasmuch as the screening test, designed to detect homozygotes (Beutler and Baluda, 1966a) only incidentally detected the heterozygotes and variants defined here.

\section{REFERENCES}

Beutler, E. and Baluda, M. C. (1966a). A simple spot screening test for galactosemia. Fournal of Laboratory and Clinical Medicine, 68, 137-141.

Beutler, E. and Baluda, M. C. (1966b). Improved method for measuring galactose-1-phosphate uridyl transferase activity of erythrocytes. Clinica Chimica Acta, 13, 369-379.

Beutler, E., Baluda, M. C., Sturgeon, P., and Day, R. W. (1966). The genetics of galactose-1-phosphate uridyl transferase deficiency. Fournal of Laboratory and Clinical Medicine, 68, 646-658.

Beutler, E. and Mitchell, M. (1968). New rapid method for the estimation of red cell galactose-1-phosphate uridyl transferase activity. Fournal of Laboratory and Clinical Medicine, 72, 527-532.

Kelly, S., Katz, S., Burns, J., and Boylan, J. (1970). Screening for galactosemia in New York State. Public Health Reports, 85, 575578.

Mathai, C. K. and Beutler, E. (1966). Electrophoretic variation of galactose-1-phosphate uridyltransferase. Science, 154,1179-1180.

Ng, W. G, Bergren, W. R., Fields, M., and Donnell, G. N. (1969). An improved electrophoretic procedure for galactose-1-phosphate uridyl transferase: demonstration of multiple activity bands with the Duarte variant. Biochemical and Biophysical Research Communications, 37, 354-362. 